\title{
ARKHIMÉDÉSZ-FÉLE SPIRÁLIS FOGIRÁNYVONALÚ HENGERES FOGASKEREKEK FOGLÁBFELÜLETÉNEK MODELLEZÉSE
}

\section{THE MODELING OF DEDENDUM TRANSITION SURFACES BY CYLINDRICAL GEARS WITH ARCHIMEDEAN SPIRAL SHAPED TOOTHLINE}

\author{
Máté Márton ${ }^{1}$, Hollanda Dénes ${ }^{2}$ \\ (1) Sapientia Erdélyi Magyar Tudományegyetem, Müszaki és Humán Tudományok \\ Kar, Gépészmérnöki Tanszék. Cím: Románia, Marosvásárhely/Koronka, Segesvári \\ út 1C Telefon / Fax: +40-265-206210/ +40-265-206211. Levelezési cím: \\ mmate@ms.sapientia.ro
}

(2) Sapientia Erdélyi Magyar Tudományegyetem, Müszaki és Humán Tudományok Kar, Gépészmérnöki Tanszék. Cím: Románia, Marosvásárhely/Koronka, Segesvári út 1C Telefon / Fax: +40-265-206210/ +40-265-206211. Levelezési cím: hollanda@ms.sapientia.ro

\begin{abstract}
Cylindrical gears having the tooth line shaped by an Archimedean spiral were recently developed in the frame of a research contract supported by the Hungarian Academy of Sciences [1]. As well as known, most used cylindrical gears are the classical spur gears or helical gears forming an exterior or interior gear couple. Theory of these gears was developed and technology perfected longtime ago. Despite of this fact it still exist a challenge here. It consists in finding new ways to increase the load capacity and the quality of the teeth contact at equivalent dimensions in comparison with the classical cylindrical involute gears. Cylindrical gears having the tooth line shaped by an Archimedean spiral combine successfully the advantages of shaping using one common rake type tool [2] and those offered by the bevel gear cutting technologies regarding the localization of the contact patch. In our opinion there exist two basic aspects of the geometry that influence the load capacity: the values of curvatures on the tooth surfaces [3] and the shape of the dedendum transition surface situated between the enveloped tooth surface and the dedendum circle. This paper presents the geometrical model of the tooth dedendum transition surface. It starts from the general concepts of modeling the edge of the cutting tool, and continues with the discussion of the surface family generated by the tool's edge. The paper ends with conclusions regarding the further possible developments.
\end{abstract}

Keywords: involute, Archimedean spiral, tooth dedendum, modeling.

\section{Összefoglalás}

Az Arkhimédész-féle spirális fogirányvonalú hengeres fogaskerekeket a Magyar Tudományos Akadémia segítségével megvalósult kutatási program keretében fejlesztettük ki [1]. Amint ismeretes, a hengeres evolvens fogaskerekek egyenes vagy ferde fogazású, külső vagy belső kapcsolódású fogaskerekek. Ezek elmélete és gyártástechnológiája mára már teljes egészében felfedezett és a végletekig tökéletesített. Mindezek ellenére a hengeres fogaskerekek területén továbbra is fennáll és egyre erősebb az a kihívás, aminek tétjét a fogak érintkezésének a tökéletesítése, valamint a teherbírás növelése képezi, a klasszikus fogaskerekekkel azonos méretek megtartása mellett. Az Arkhimédész-féle spirális fogirányvonalú fogakkal rendelkező hengeres fogaskerekek sikeresen ötvözik az egyetlen, fogasléc 
típusú szerszámmal való lefejthetőség [2] és a kúpfogaskerekek hordkép-lokalizációra irányuló megoldások előnyeit. Nézetünk szerint két geometriai aspektus befolyásolja lényegesen a fogak terhelhetőségét és megfelelő kapcsolódását: a fogfelületek érintkezési pontokban felvett görbületeinek viszonya [3] és a foglábfelület alakja. Jelen dolgozat részletesen foglalkozik a vizsgált fogaskerékre jellemző foglábfelület lefejtésével, alakjának befolyásolhatóságával, valamint a reális származtatófelületekkel. Elsőként a szerszámél csatlakoztató részének modellezését tárgyalja, ezt követően a foglábfelületet kialakító reális fogfelületsereg egyenleteinek levezetését nyújtja, majd a foglábfelület optimalizálásának lehetőségeivel zárul.

Kulcsszavak: evolvens, Arkhimédész-féle spirál, fogláb, modellezés

\section{Az Arkhimédész-féle spirális fogirányvonalú hengeres fogas- kerekek lefejtésének elve}

Az Archimédesz-féle spirális fogirányvonalú fogaskerékpár lefejtési elvét az $\mathbf{1}$. ábrán szemléltetjük $[1,2]$. Az ábra bal oldalán felülnézetben látható a lefejtőszerszám elvi vázlata. Amint megfigyelhető, a kúpfogaskerék-marófejekhez hasonló felépítés $z_{\mathrm{s}}$ számú, Arkhimédészféle spirálgörbére tájolt, egyenlő szögbeosztású, fogasléc-profil élvezetésű kést egyesít. A forgástengely a bal oldali vázlat síkjára merőleges. Amint a szerszámot óramutató járásával megegyező irányban forgatni kezdjük, $\omega_{\mathrm{H}}$ szögsebességgel, bármely sugár irányában az $a \omega_{\mathrm{H}}$ sebességgel haladó fogaslécprofilt találjuk, amelyet matematikai modellként értelmezünk [4,5], és beírjuk két kapcsolódó fogaskerék közé, amint az 1. ábra jobb oldalán szemléltettük. Tudván, hogy az Arkhimédész-féle spirális vezérgörbe paramétere $a=0,5 m$, és így a fogasléc osztóvonalmenti fogosztása $p=\pi m$, belátható, hogy elvileg a javasolt szerszám fogasléccel

egyenértékü származtatófelületek létrehozására alkalmas, így csoportkerekek megmunkálásához megfelelö [6].
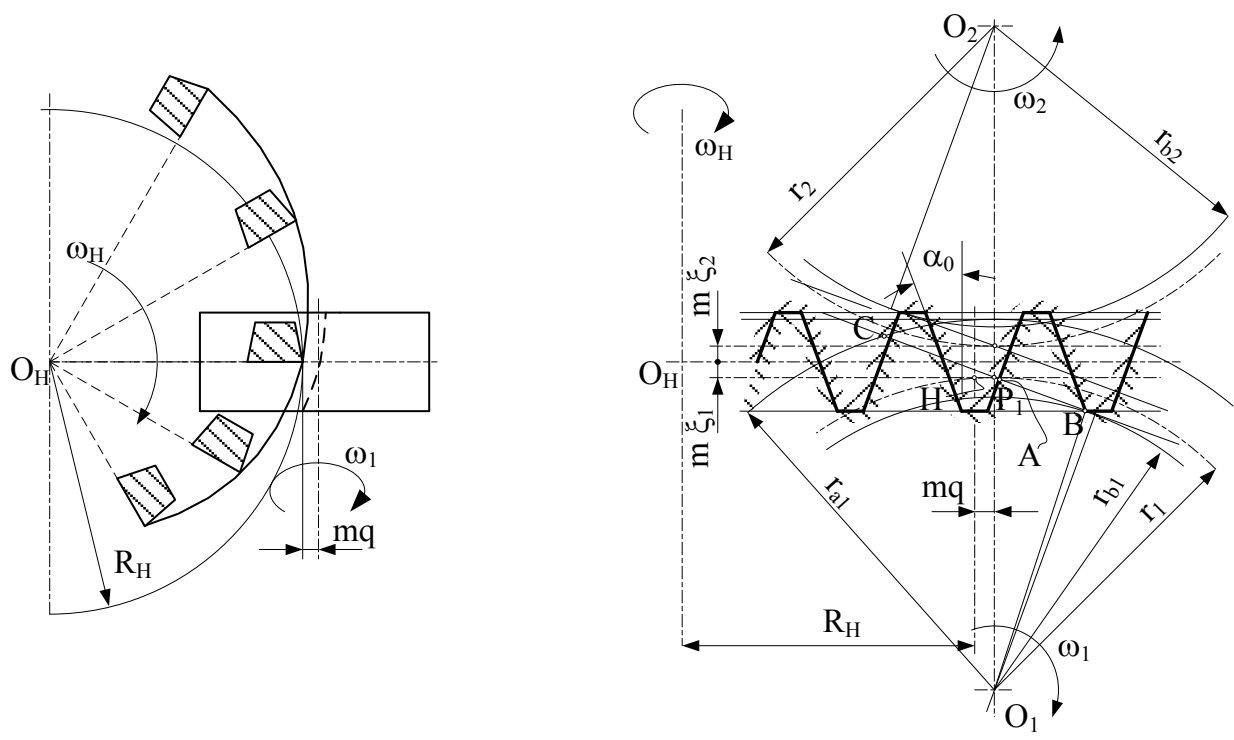

1. ábra. Az Arkhimédész-féle spirális vezérvonalú fogazat lefejtésének elvi vázlata[1,2] 
A jobb oldali vázlat kimutatja, hogy a javasolt felületszármaztatás lehetővé teszi a hagyományosan értelmezett profileltolást és a tangenciális eltolás alkalmazását is, aminek következtében az érintkező fogak görbületeit a pontszerü érintkezés megvalósítása céljából módosítja. Az érintkező fogfelü- leteket az [1]-ben részletesen kifejtett matematikai modell alapján kapjuk meg. A tökéletesen illeszkedő hordkép kimutatása az Inventor szoftver felhasználásával történt, aminek során a fogoldalak egymásba forgatásának elvét alkalmaztuk [3,4]. A modellt a 2. ábrán szemléltetjük.

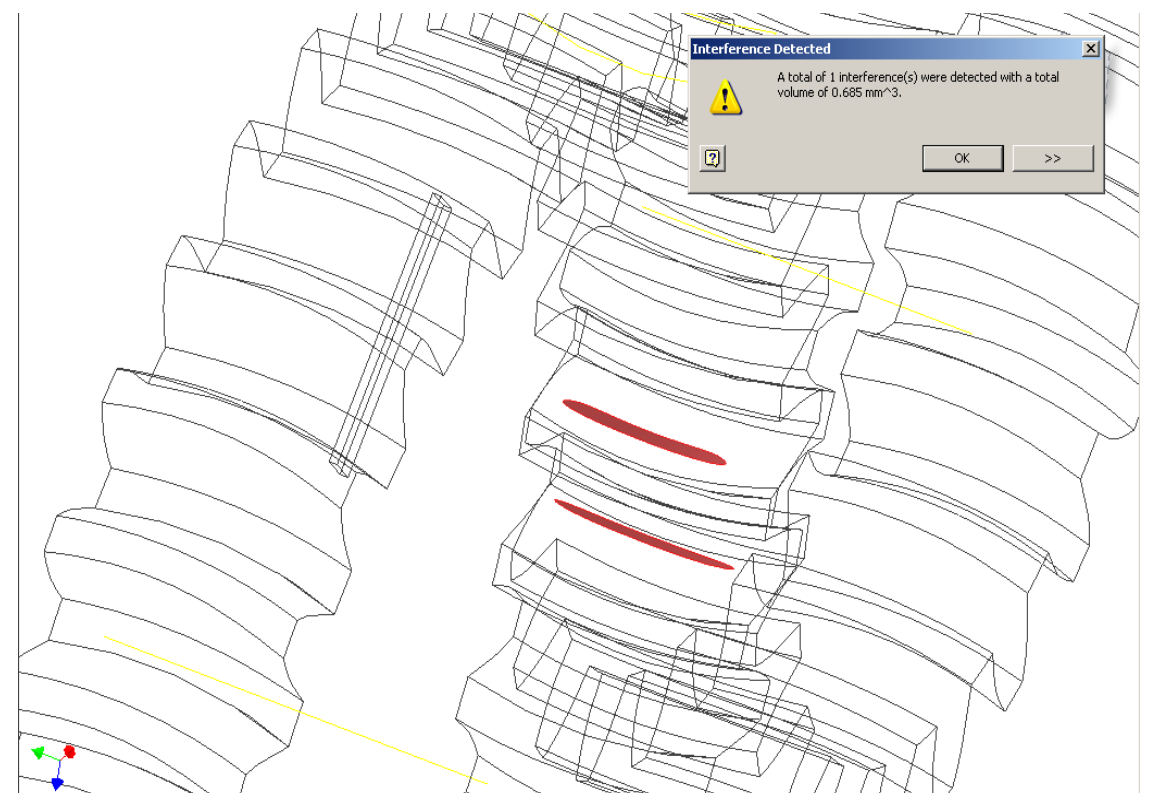

2. ábra. A kapcsolódó fogoldalak és a hordkép helyzete [3]

\section{A foglábfelület kialakítása}

\subsection{A foglábfelület sajátosságai a gör- be fogú hengeres kerekek eseté- ben}

Az egyenes- vagy dőltfogú hengeres kerekek esetében a foglábgörbe a fogaskerék tengelyére merőleges síkban pontosan tanulmányozható. Ez a lefejtés azon sajátosságának köszönhető, hogy bármely tengelyre merőleges szelvényben a burkolás azonos módon történik. Ezekben az esetekben jó közelítéssel állítható, hogy a léc típusú szerszámmal lefejtett fogazatok foglábgörbéje a szerszámél legtávolabbi pontja által leírt hurkolt evolvens, a metszőkerék- kel lefejtett fogazatoknál hurkolt epiciklois $[4,6]$. A fogaskerékgyártó-szerszámszabványok $[7,8,9,10]$ a lefejtőszerszám fogának fejszalagéle és oldaléle közötti csatlakoztatást körívvel, esetleg lecsapással (egyenes szakasszal) oldják meg. Ez esetben a burkolt felület tengelyre meröleges szelvénye közelítőleg azonos az elméleti görbékkel.

A görbe fogú hengeres fogaskerék esetében evolvensprofil kizárólag a lefejtőszerszám azon tengelysíkjában keletkezik, mely a fogaskerék tengelyére meröleges. Bármely más síkban a klasszikus evolvenslefejtéshez képest „csúszás” áll elö, így a foglábfelület igen összetett mó- 
don változik. Jelen modellezésnek pontosan az a végső célja, hogy elkerüljük azokat a beállításokat, amelyek következtében megengedhetetlenül terjedelmes foglábfelületzónák jönnének létre, és elóállna a foglábfelület és a hasznos fogfelület kapcsolódásának lehetősége is.

A foglábfelület görbületét lényegesen befolyásolja az ezt elő́llító szerszámélrész görbülete. Annak érdekében, hogy a foglábfelületet a lehető legfinomabban tudjuk módosítani, a lefejtőszerszám élcsúcsszakaszát polinomként modellezzük.

\subsection{A szerszám élcsúcsgörbéje}

A szerszám élcsúcsgörbéjét a lábhézag kivágásához szükséges, $0.25 \mathrm{~m}$ magasságig terjedő oldalélszakaszra, illetve a fejél feléig terjesztjük ki elméletileg. A görbe meghatározó elemeit a 3. ábrán szemléltetjük.

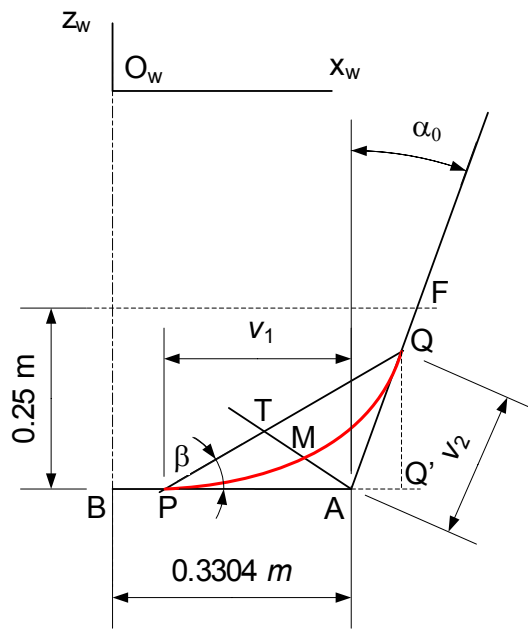

3. ábra. A szerszám élcsúcsgörbéje

Az élcsúcsgörbe az $O_{\mathrm{w}} x_{\mathrm{w}} y_{\mathrm{w}} z_{\mathrm{w}}$ koordináta-rendszerben értelmezett, melynek origója a fogprofil szimmetriatengelyének és a szerszámléc osztóvonalának metszéspontja. A görbe $P$ kezdőpontja az $A B, Q$ végpontja pedig az $A F$ szakaszon található, helyzetüket a $v_{1}$, illetve $v_{2}$ paraméterek segítségével szabályozzuk. A 3. ábra alapján felírható, hogy

$$
\left\{\begin{array}{l}
x_{w}^{(A)}=\frac{m \pi}{4}+\frac{j}{2}-\left(h_{0 a}^{*}+c_{0}^{*}\right) m \operatorname{tg} \alpha_{0} \\
z_{w}^{(A)}=-\left(h_{0 a}^{*}+c_{0}^{*}\right) m \\
A F=c_{0}^{*} m / \cos \alpha_{0} \\
v \cdot \in\left(0, x_{w}^{(A)}\right] ; v_{2} \in(0, A F]
\end{array}\right.
$$

A modellezett csatlakoztatási görbe a $P A Q$ háromszög területén belül illeszkedö, a $P$ és $Q$ pontokat összekötő görbe, melynek határhelyzete maga a $P Q$ egyenes. A továbbiakban a $P Q Q$ ' és a $P A Q$ háromszögekből

$$
\begin{aligned}
P Q & =\left(v_{1}^{2}+v_{2}^{2}+2 v_{1} v_{2} \sin \alpha_{0}\right)^{\frac{1}{2}} \\
\sin \beta & =\frac{Q Q^{\prime}}{P Q}=\frac{v_{2} \cos \alpha_{0}}{\left(v_{1}^{2}+v_{2}^{2}+2 v_{1} v_{2} \sin \alpha_{0}\right)^{\frac{1}{2}}} \\
\cos \beta & =\frac{P Q^{\prime}}{P Q}=\frac{v_{1}+v_{2} \sin \alpha_{0}}{\left(v_{1}^{2}+v_{2}^{2}+2 v_{1} v_{2} \sin \alpha_{0}\right)^{\frac{1}{2}}}
\end{aligned}
$$

A következö lépés a görbe harmadik kontrollpontjának a felvétele. Ez a $T$ pont, mely a $P Q$ határegyenesen illeszkedik, és meghatározó paramétere a $v_{3}, v_{3}=P T / P Q, v_{3} \in(0,1)$. A $T$ pont koordinátái a következök lesznek:

$\left\{\begin{array}{l}x_{w}^{(T)}=x_{w}^{(A)}-v_{1}+v_{3} P Q \cos \beta= \\ =x_{w}^{(A)}-v_{1}+v_{3}\left(v_{1}+v_{2} \sin \alpha_{0}\right) \\ z_{w}^{(T)}=z_{w}^{(A)}+v_{3} v_{2} \cos \alpha_{0}\end{array}\right.$

Végül a görbe negyedik kontrollpontját, egyben a görbe belső pontját határozzuk meg. Az M pont az AT szakaszon illeszkedik, és helyzetét a $\mathrm{v}_{4}$ paraméter határozza meg, amely a $v_{3}$-hoz hasonlóan töredékrészt fejez ki, tehát $v_{4}, v_{4}=A M / A T, v_{4} \in(0,1)$. 


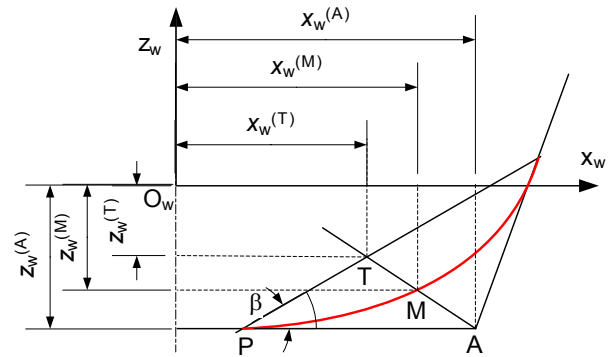

4. ábra. Az élcsúcsgörbe belső kontrollpontjának definiciója
A 4. ábra alapján és a (3-as) képletek figyelembevételével felírhatók az M pont koordinátái:

$$
\left\{\begin{array}{l}
x_{w}^{(M)}=x_{w}^{(A)}+v_{4}\left(x_{w}^{(T)}-x_{w}^{(A)}\right)= \\
=x_{w}^{(A)}+v_{4}\left(-v_{1}+v_{3}\left(v_{1}+v_{2} \cos \alpha_{0}\right)\right) \\
z_{w}^{(M)}=z_{w}^{(A)}+v_{4}\left(z_{w}^{(T)}-z_{w}^{(A)}\right)= \\
=z_{w}^{(A)}+v_{2} v_{3} v_{4} \cos \alpha_{0}
\end{array}\right.
$$

A $P, Q$ és $M$ pontok koordinátái birtokában az élcsúcsgörbét negyedfokú polinomként írjuk fel, az alábbi feltételrendszer alapján:

$$
\begin{aligned}
& \mathrm{f}\left(x_{w}\right)=\sum_{i=0}^{4} a_{i} x_{w}^{i} \\
& \mathrm{f}\left(x_{w}^{(P)}\right)=z_{w}^{(A)} \Leftrightarrow \sum_{i=0}^{4} a_{i}\left(x_{w}^{(A)}-v_{1}\right)^{j}=z_{w}^{(A)} \\
& \mathrm{f}^{\prime}\left(x_{w}^{(P)}\right)=0 \Leftrightarrow \sum_{i=1}^{4} i a_{i}\left(x_{w}^{(A)}-v_{1}\right)^{i-1}=0 \\
& \mathrm{f}\left(x_{w}^{(Q)}\right)=z_{w}^{(Q)} \Leftrightarrow \sum_{i=0}^{4} a_{i}\left(x_{w}^{(A)}+v_{2} \sin \alpha_{0}\right)^{j}=z_{w}^{(A)}+v_{2} \cos \alpha_{0} \\
& \mathrm{f}^{\prime}\left(x_{w}^{(Q)}\right)=\operatorname{ctg} \alpha_{0} \Leftrightarrow \sum_{i=1}^{4} i a_{i}\left(x_{w}^{(A)}+v_{2} \sin \alpha_{0}\right)^{-1}=\operatorname{ctg} \alpha_{0} \\
& \mathrm{f}\left(x_{w}^{(M)}\right)=z_{w}^{(M)} \Leftrightarrow \sum_{i=0}^{4} a_{i}\left(x_{w}^{(A)}+v_{4}\left(-v_{1}+v_{3}\left(v_{1}+v_{2} \cos \alpha_{0}\right)\right)\right)^{j}=z_{w}^{(A)}+v_{2} v_{3} v_{4} \cos \alpha_{0} \\
& f^{\prime \prime}\left(x_{w}\right)<0, \forall x_{w} \in\left(x_{w}^{(A)}-v_{1}, x_{w}^{(A)}+v_{2} \sin \alpha_{0}\right)
\end{aligned}
$$

Az (5) feltételrendszer a $v_{i}, i \in \overline{1,4}$ kontrollparaméterek ismeretében öt ismeretlenes lineáris egyenletrendszerré alakul, amelynek megoldása a negyedfokú élcsúcsgörbe polinomiális együtthatói. Ha a négy kontrollparamétert egyenrangúként kezeljük, akkor négyszeres végtelenség görbét találhatunk. Az optimális megoldás célratörőbb meghatározása érdekében elfogadjuk, hogy a $P$ és $Q$ pontok helyzetét kijelölő $v_{1}$ és $v_{2}$ paraméterek föparaméterek, amelyeket először jelölünk ki. A következő lépésben kijelöljük a $T$ kontrollpont helyzetét a $P Q$ határszakaszon.
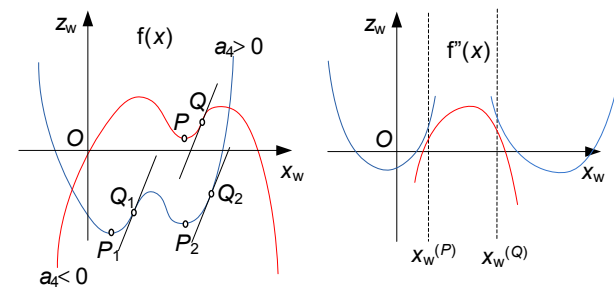

5. ábra. Az élcsúcsgörbe konkavitását biztositó feltételek grafikus ábrázolása 
A negyedik paraméter számára meg kell határoznunk azt az intervallumot, amely biztosítja a második derivált szigorú pozitivitását, ami szükséges és elégséges feltétele az inflexiópontok nemlétezésének és a görbe domborúságának a kijelölt pontok között.

A második derivált pozitivitásának a feltételét az 5. ábrán szemléltettük. Ha negyedfokú polinom legnagyobb fokú együtthatója negatív, akkor egyetlen maximuma vagy két helyi maximumpontja és egyetlen helyi minimumpontja van - értelemszerüen a görbe lehetséges felhasználási szakasza a $P$ és $Q$ pontok közé eső szakasz; amennyiben $a_{4}>0$ (kék görbe) és rendelkezik három lokális extrémummal, a grafikus képen két domború, növekvő szakaszt különíthetünk el. A második derivált előjelére ennek függvényében az alábbi kikötéseket teszszük:

- ha $a_{4}<0$, és a másodrendü derivált diszkriminánsa $9 a_{3}^{2}-24 a_{2} a_{4} \leq 0, \quad \mathrm{a}$ negyedfokú polinom grafikus képe folytonosan homorú, tehát a görbe alkalmtlan;

- ha $a_{4}<0$, és a másodrendü derivált diszkriminánsa $9 a_{3}^{2}-24 a_{2} a_{4}>0, \quad$ a negyedfokú polinom grafikus képének domborúsága akkor biztosított, ha az élcsúcsgörbe szélső pontjainak abszcisszái az inflexiópontok abszcisszái között illeszkednek;

- ha $a_{4}>0$, és a másodrendü derivált diszkriminánsa $9 a_{3}^{2}-24 a_{2} a_{4} \leq 0$, a negyedfokú polinom grafikus képe folytonosan domború;

- ha $a_{4}>0$, és a másodrendü derivált diszkriminánsa $9 a_{3}^{2}-24 a_{2} a_{4}>0, \quad$ a negyedfokú polinom grafikus képének domborúsága akkor biztosított, ha az élcsúcsgörbe szélső pontjainak abszcisszái által meghatározott intervallum az inflexiópontok abszcisszáinak intervallumán kívül esik;

- A domborúság feltétele mellé elengedhetetlenül be kell iktatni a folytonos növekvés korlátját is, az élcsúcsgörbe alakjából kiindulva.

A fenti feltételek a $v_{3}$ és $v_{4}$ paraméterek értéktartományát hatékonyan leszükítik. A számítások bonyolultsága elengedhetetlenné teszi a számítógépes feldolgozást. Az élcsúcsgörbe parametrikus egyenletei a domború szerszámoldalon [1] a következők lesznek:

$$
\left\{\begin{array}{l}
x_{w}(t)=t \\
y_{w}(t)=0 \\
z_{w}(t)=\sum_{i=0}^{4} a_{i} t^{i}
\end{array}\right.
$$

\section{A származtató felületek sokasága}

\subsection{A foglábfelület generálásának feltételei}

A burkolófelületek felírásában és elemzésében leghatékonyabbnak bizonyuló szakirodalom [4,5] azt az elvet követi, miszerint a burkolófelület a szerszámélek által létrehozott felületsereg burkolójaként jön létre. A burkolt felület felírásában a legtöbb esetben egyszerüsítés áll fenn, mely abból a tényből ered, hogy gyakran köszörüszerszámot használnak modellként. Véges számú vágóél esetében a burkolt felületet a szerszámélek illeszkedő felülete adja, amely a szerszám munkadarabhoz viszonyított relatív mozgása során hozza létre a felületsereget.

Jelen dolgozatban egy alternatív modellt mutatunk be. Ennek lényege abból áll, hogy a burkolt felületet a szerszám éle a munkadarab rendszerében, a szerszámmunkadarab relatív elmozdulása során hozza létre, $v a$ - 
gyis a burkolt felületsereg adott elemének a vágóél-paramétertöl különbözö második paramétere pontosan a relatív mozgást jellemzö kinematikai paraméter. A „léptetés” a vágóélek helyzetének pontos felírása, illetve az él belépése pillanatának pontos ismeretében írható fel. Az így keletkezett burkolt felületsereg diszkrét, mivel véges számú elemből áll. A legvalósághübb burkolófelületet az egymást követő burkolt felületek metszésgörbéire felírt splinefelülettel lehet közelíteni. Ha matematikailag szeretnénk pontos eredményt, az így kapott diszkrét felületsereget úgy alakítjuk át végtelen elemü halmazzá, hogy a burkolt élek számát végtelenítjük, azaz az osztást folytonos változóként kezeljük.

\subsection{A szerszámél-felületek meghatá- rozása}

Jelen modellt az [1]-ben részletesen leírt szerszámra építjük. Megemlítjük, hogy a

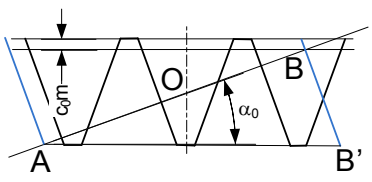

a.

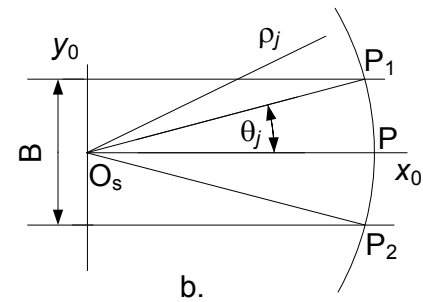

6. ábra. A generálófelületek meghatározása

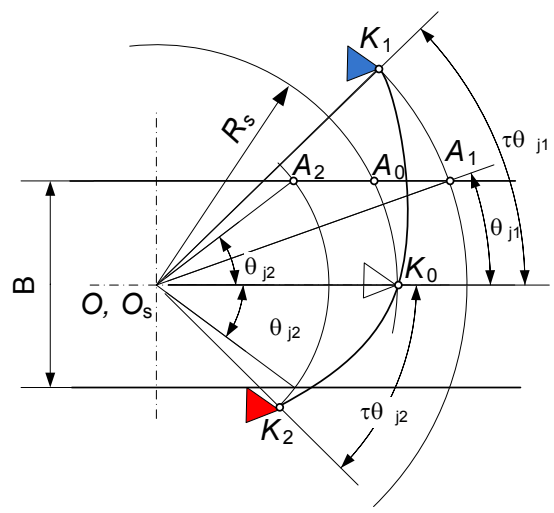

7. ábra. Akések belépésének vázlata fogazószerszámnak $R_{\mathrm{s}}$ referenciasugara annak a késnek a szerszámtengelytől való profil-szimmetriavonal-távolságát jelöli, amely nulla tangenciális profileltolás esetén a fogárok radiális szelvényének szimmetriavonalára esik. Ettől a ponttól számítjuk a kések kiosztási szögét. A 6.a. ábra alapján azonnal felírható a kések kiosztási szöge tudva, hogy a spirális paramétere $0.5 \mathrm{~m}$ :

$$
\varphi_{\Sigma s}=4\left(2 h_{o a}^{*}+c_{0}^{*}\right) / \sin 2 \alpha_{0}
$$

A késeknek egymáshoz viszonyított helyzetét indexszel jelöljük. A „0"-dik kés az alaphelyzetben $R_{\mathrm{S}}$ távolságra illeszkedik a forgástengelytöl. A ,j”-edik kés távolsága

$$
R_{j}=R_{s}+j \tau \frac{m}{2}, \quad \tau=\frac{2 \pi}{z_{s}} .
$$

A szerszám forgásiránya az óramutató járásával megegyező, tehát az alaphelyzetben levő lefejtő hajtás esetén a negatív indexü kések már elhaladtak, a pozitív indexüek pedig érkeznek. A kések számának pontos meghatározása az [1] -ben található.

A késél csak addig generálja a foglábfelület anyagi részét, ameddig a fogazandó kerék határsíkjai közé illeszkedik. Az él különböző pontjainak a szerszám forgástengelyéhez viszonyított távolsága változik, ezért a legnagyobb $\theta$ szöget az élcsúcsgörbe $P$ pontjára kapunk, melynek sugara: 


$$
\rho_{j}=R_{j}+x_{w}^{(A)}-v_{1}
$$

Jelöljük a továbbiakban a lefejtő hajtás áttételét $i_{1 \mathrm{~s}}$-sel, ahol $i_{1 s}=\omega_{1} / \omega_{s}=1 / z_{1}$. A lefejtő hajtáshoz tartozó alkalmazott koordináta-rendszerek helyzete a 8. ábrán látható. $\mathrm{Az} O x_{0} y_{0} z_{0}$ rendszer rögzített. $\mathrm{A}$ szerszám $O_{\mathrm{s}} x_{\mathrm{s}} y_{\mathrm{s}} z_{\mathrm{s}}$ rendszere alaphelyzetben a rögzített rendszerrel egybeesik. A fogazandó kerék $O_{1} x_{1} y_{1} z_{1}$ rendszere alapállásban az álló rendszerrel párhuzamos illeszkedésü. Az alapállás a „O”-dik kés középállásának felel meg, vagyis az a helyzet, amikor a generáló profil síkja az álló rendszer $y_{0} z_{0}$ síkjába illeszkedik. A „,O’-dik kés belépésének pillanatában a szerszám rendszere a forgásirányához képest ellenkező irányban van elfordítva, $\theta_{0}$ szöggel. Ennek a helyzetnek megfelelően a fogazandó kerék is forgásirányával ellentétesen kell legyen elfordítva, $i_{1 s} \theta_{0}$-val. A ,j"-edik késnek ,O"-dik késhez viszonyított helyzetét a $j \tau$ központi szög határozza meg. A ,j"'-edik kés belépése akkor kezdődik, amikor az alaphelyzethez viszonyítva a szerszám rendszere $\psi_{\mathrm{j}}$ szöggel fordult el:

$$
\psi_{j}=\tau j-\theta_{j}, \quad j \in \mathbf{Z} .
$$

Innen a fogazandó kerék elfordulási szöge könnyen számítható, mivel $\lambda_{j}=i_{1 s} \psi_{j}$.

A fentebb említett geometriai viszonyokat a 7. ábrán tüntettük fel. A referencia sugárnál nagyobb sugáron illeszkedő $K_{1}$ kés $j_{1}$ indexe pozitív, míg az ennél kisebb sugáron illeszkedő $K_{2}$ kés negatív indexü. A $K_{\mathrm{j}}$ kések belépési pontjai az $A_{\mathrm{j}}$ pontok. Megfigyelhetö, hogy a (10)-es képlet elöjeltől függetlenül érvényes.

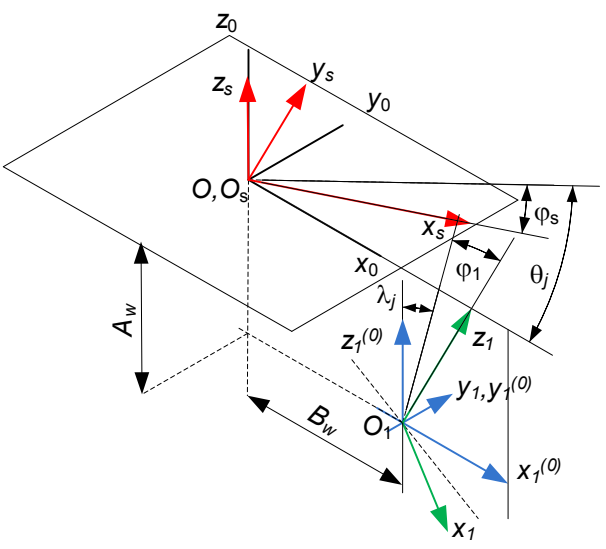

8. ábra. Az alkalmazott koordináta-rendszerek

A fogél által generált felület parametrikus egyenleteit a 8. ábra alapján a fogaskerék rendszerében írjuk fel:

$$
\mathbf{r}_{1}=\mathbf{M}_{10} \mathbf{M}_{0 s} \mathbf{r}_{s}
$$

ahol a transzformációs mátrixok a kinematikai paraméternek és a helyzetparaméternek a függvényei:

$$
\begin{aligned}
\mathbf{M}_{10}\left(\lambda_{j}, \varphi_{s}\right) & =\left(\begin{array}{cccc}
\cos \left(\lambda_{j}+i_{1 s} \varphi_{s}\right) & 0 & -\sin \left(\lambda_{j}+i_{1 s} \varphi_{s}\right) & B_{w} \\
0 & 1 & 0 & 0 \\
\sin \left(\lambda_{j}+i_{1 s} \varphi_{s}\right) & 0 & \cos \left(\lambda_{j}+i_{1 s} \varphi_{s}\right) & -A_{w} \\
0 & 0 & 0 & 1
\end{array}\right) \\
\mathbf{M}_{0 s}\left(\theta_{j}, \varphi_{s}\right) & =\left(\begin{array}{cccc}
\cos \left(\theta_{j}-\varphi_{s}\right) & -\sin \left(\theta_{j}-\varphi_{s}\right) & 0 & 0 \\
\sin \left(\theta_{j}-\varphi_{s}\right) & \cos \left(\theta_{j}-\varphi_{s}\right) & 0 & 0 \\
0 & 0 & 1 & 0 \\
0 & 0 & 0 & 1
\end{array}\right)
\end{aligned}
$$


A generálógörbe koordinátáinak homogén oszlopmátrixa ebben az esetben szintén helyzetparaméter-függő:

$$
\mathbf{r}_{s}(j, t)=\left(\begin{array}{c}
R_{s}+\tau j+t \\
0 \\
\sum_{i=0}^{4} a_{i} t^{i} \\
1
\end{array}\right)=\left(\begin{array}{c}
t \\
0 \\
\sum_{i=0}^{4} a_{i} t^{i} \\
1
\end{array}\right)+\left(\begin{array}{c}
R_{s}+\tau j \\
0 \\
0 \\
0
\end{array}\right)=\mathbf{r}_{s}(t)+\mathbf{r}_{s}(j) .
$$

\section{Következtetések}

Jelen matematikai modell alkalmazása úgy történik, hogy rögzítünk egy tetszöleges $\quad\left(\begin{array}{llll}v_{1} & v_{2} & v_{3} & v_{4}\end{array}\right) \quad$ élcsúcsgörbeparaméternégyest, a 2.-es szakaszban leírtak alapján, majd kiszámítjuk a burkolt foglábfelületet. A számítások alapján lehetőség nyílik a pontos, valósághü testmodell megépítésére. A végeselemes vizsgálat alapján kimutathatóvá válnak a fogtőben fellépő feszültségek, melyeknek értékeit kapcsolatba hozzuk a generáló szerszám élcsúcsgörbéjének megfelelö pontjaival, és ezáltal esély nyílik arra, hogy véges számú programfuttatással megtaláljuk a lehető legkedvezőbb szerszámkialakítást.

Megemlítjük, hogy a fentebb vázolt modell a kapcsolódó fogoldalak valós egyenleteinek kiszámítására is alkalmas. Ebben az esetben a generálógörbe oszlopmátrixának helyzetfüggetlen összetevőit a lécprofil parametrikus egyenletei teszik ki.

\section{Szakirodalmi hivatkozások}

[1] Máté, M.: Spirálfogazatú hengeres kerekek geometriája és gyártástechnológiája. Magyar Tudományos Akadémia, Domus Hungarica egyéni kutatási ösztöndíj, B2011061 sz. Nyertes pályázat.

[2] Máté, M., Hollanda, D.: The Cutting of Cylindrical Gears Having Archimedean Spiral Shaped Tooth Line. 13th International Conference on Tools, 27-28 March 2012, Miskolc, ISBN 978-963-9988-35-4, 357-362.
[3] Máté, M., Hollanda, D., Tolvaly-Roşca, F., Popa-Müller, I.: Az Arkhimédész-féle spirális vezérgörbéjü fogazat hordképének lokalizációja a tangenciális eltolás megfelelö beállitásával. XXI-ik OGÉT-2013, Arad, ápr. 25-28. Konferenciakötet, ISSN 2068-1267, 265-268.

[4] Litvin, F. L.: A fogaskerékkapcsolás elmélete. Budapest, Müszaki Könyvkiadó, 1972.

[5] Dudás, I. The Theory and Practice of Worm Gear Drives. Penton Press, London, 2000.

[6] Szeniczei, L.: Általános fogazás. Nehézipari Müszaki Könyvkiadó, 1952.

[7] ISO 4468:2009. Gear hobs - Accuracy requirements.

[8] ISO 2490:2007. Solid (monobloc) gear hobs with tenon drive or axial keyway, 0,5 to 40 module - Nominal dimensions.

[9] DIN 1829-1 Schneidräder für Stirnräder; Bestimmungsgrößen, Begriffe, Kennzeichnung.

[10] DIN 1829-2 Schneidräder für Stirnräder; Toleranzen, Zulässige Abweichungen.

\section{Köszönetnyilvánítás}

A kutatás az Európai Unió és Magyarország támogatásával, az Európai Szociális Alap társfinanszírozásával a TÁMOP 4.2.4.A/2-11-1-2012-0001 azonosító számú „Nemzeti Kiválóság Program - Hazai hallgatói, illetve kutatói személyi támogatást biztosító rendszer kidolgozása és müködtetése konvergencia program" címü kiemelt projekt keretei között valósult meg.

\section{Acknowledgement}

This research was supported in the framework of TÁMOP 4.2.4. A/2-11-1- 
2012-0001 „National Excellence Program Elaborating and operating an inland student and researcher personal support system" key project. The project was subsidized by the European Union and co-financed by the European Social Fund. 